\title{
Analisis Kesulitan Belajar dalam Memahami Kecemasan Peserta Didik pada Pembelajaran Matematika
}

\author{
Wantika1, Sri Purwanti Nasution ${ }^{1}$ \\ ${ }^{1}$ Universitas Islam Negeri Raden Intan Lampung. Jalan Endro Suratmin, Sukarame, Bandar \\ Lampung 35133, Indonesia. \\ *Corresponding Author. E-mail: onetika347@gmail.com
}

\begin{abstract}
Abstrak
Penelitian ini dilatar belakangi oleh masalah yang terjadi pada mata pelajaran Matematika, di mana sebagian besar kontennya bersifat abstrak, tidak sedikit peserta didik yang merasa kesulitan dalam mempelajarinya. Hal ini harus mendapat perhatian khusus dari beberapa pihak, seperti guru, lingkungan sekolah, wali peserta didik, dan lingkungan sekitar. karena mata pelajaran Matematika merupakan salah satu pelajaran wajib yang harus dipelajari semua jenjang pendidikan dasar dan menengah. Penelitian ini bertujuan untuk mendeskripsikan kesulitan belajar dalam memahami kecemasan peserta didik pada pembelajaran Matematika kelas X di SMA Muhammadiyah 1 Kotaagung Kabupaten Tanggamus. Dalam penelitian ini jumlah populasi sebanyak 37 peserta didik dengan teknik sampling dalam penelitian ini menggunakan purposive sampling dan acak kelas. Pengumpulan data dalam penelitian ini berupa catatan lapangan data menggunakan dokumentasi, observasi, angket, dan wawancara. Kesulitan belajar dapat diartikan sebagai suatu kondisi dalam proses belajar yang ditandai oleh adanya hambatan-hambatan tertentu untuk mencapai hasil belajar. Pada penelitian ini lebih mangacu pada permasalahan kecemasan peserta didik yang menjadi penghambat dalam mencapai tujuan pembelajaran. Penelitian ini merupakan jenis penelitian kualitatif dan teknik validitas dalam penelitian ini menggunakan triangulasi waktu. Berdasarkan hasil analisis data dan pembahasan kesulitan belajar dalam memahami peserta didik pada pembelajaran Matematika dapat disimpulkan bahwa faktor yang mempengaruhi kesulitan belajar yaitu faktor internal fisik dan fisikis serta faktor eksternal yaitu faktor keluarga dan lingkungan. Kecemasan peserta didik dengan kategori kecemasan rendah lebih terlihat tanggap dan sangat bersemangat dalam pembelajaran Matematika dibandingkan dengan dua kategori lainnya yaitu kategori kecemasan sedang dan kecemasan tinggi.
\end{abstract}

Kata kunci: Kesulitan Belajar, Kecemasan Peserta Didik, Pembelajaran Matematika

\section{Abstract}

This study is based on the problems that occur in mathematics subjects, where most of the content is abstract, not a few students who find it difficult to learn. This should receive special attention from several parties, such as teachers, school environment, guardians, and the environment. because the subjects of mathematics is one of the mandatory lessons that must be studied all levels of primary and secondary education. This study aims to describe learning difficulties in understanding the anxiety of learners on learning mathematics class $X$ in SMA Muhammadiyah 1 Kotaagung Tanggamus District. In this study population of 37 students with sampling technique in this study using purposive sampling and random class. Data collection in this research is a field data record using documentation, observation, questionnaire, and interview. Learning difficulties can be interpreted as a condition in the learning process characterized by the presence of certain barriers to achieve learning outcomes. In this study more mangacu on the subject of anxiety learners who become obstacles in achieving the objectives of learning .. This research is a type of qualitative research and validity techniques in this study using time triangulation. Based on the results of data analysis and discussion of learning difficulties in understanding students in learning mathematics can be concluded that the factors that affect learning difficulties are physical and physical factors and external factors that are family and environmental factors. Anxiety of learners with low anxiety category is more noticeable and very 
Desimal, 2 (1), 2019 - 50

Wantika, Sri Purwanti Nasution

passionate in mathematics learning compared to the other two categories namely medium anxiety category and high anxiety.

Keywords: Learning Difficulties, Anxiety Learners, Mathematics Learning

\section{PENDAHULUAN}

Namun kenyataannya mayoritas siswa mengalami kesulitan dalam mempelajari matematika (Kumalasari \& Sugiman, 2015). Supartini dalam Ayu Aji Wedaring Tias mendefinisikan bahwa: "kesulitan belajar sebagai kegagalan dalam mencapai tujuan belajar, ditandai dengan tidak menguasai tingkat penguasaan minimal, tidak dapat mencapai prestasi yang semestinya, tidak dapat mewujudkan tugas-tugas perkembangan, dan tidak dapat mencapai ting- kat penguasaan yang diperlukan sebagai prasyarat bagi kelanjutan untuk belajar di tingkat selanjutnya" (Tias \& Wutsqa, 2015). Kesulitan belajar adalah kondisi dalam suatu proses belajar yang ditandai adanya hambatan-hambatan tertentu untuk mencapai hasil belajar (Lestari, 2015). Para guru umumnya memandang semua siswa yang memperoleh prestasi belajar rendah disebut siswa berkesulitan belajar (Janurti, Dibia, \& Widiana, 2016). Untuk mengatasi masalah kesulitan belajar, guru perlu mengadakan pendekatan pribadi disamping pendekatan instruksional dalam berbagai bentuk yang memungkinkan guru dapat mengenal dan memahami siswa serta masalah belajarnya.

Kesulitan belajar tak jarang disebabkan oleh faktor kecemasan ketika mengikuti pelajaran tertentu (Marliani \& Hakim, 2015). Kecemasan merupakan hal yang normal terjadi pada setiap individu, reaksi umum terhadap stress kadang dengan disertai kemunculan kecemasan (Solihah \& Liana, 2017). Perasaan takut atau tegang dalam menghadapi suatu persoalan tersebut disebut kecemasan. Crow dan Crow dalam Shinta Dwi
Handayani mengemukakan bahwa: "kecemasan adalah sesuatu kondisi kurang menyenangkan yang dialami oleh individu yang dapat mempengaruhi keadaan fisiknya" (Handayani, 2016). Senada dengan yang dikemukakan oleh Crow dan Crow, menurut Menurut Pieter, Janiwarti, dan Saragih dalam M. Afif Aminullah mengemukakan bahwa: "ada beberapa faktor penyebab timbulnya kecemasan. Berdasarkan teori psikoanalitis, kecemasan merupakan konflik emosional antara id, ego dan superego" (Aminullah, 2013).

Kecemasan yang dialami siswa pada mata pelajaran Matematika sering disebut sebagai kecemasan Matematika (Mathematics Anxiety). Tobias dalam Annisa Dwi Kurniawati dan Mutia Fariha mendefinisikan bahwa: "kecemasan Matematika sebagai perasaan tegang dan cemas yang mengganggu proses manipulasi angka dan proses pemecahan masalah Matematika dalam kehidupan biasa maupun akademik serta dapat menghilangkan rasa percaya diri seseorang" (Fariha, 2013; Kurniawati \& Siswono, 2014). Kecemasan terhadap Matematika tidak bisa dipandang sebagai hal biasa, karena ketidakmampuan siswa dalam beradaptasi pada pelajaran menyebabkan siswa kesulitan serta fobia terhadap Matematika yang akhirnya menyebabkan hasil belajar dan prestasi siswa dalam Matematika rendah (Handayani, 2016).

Ada peserta didik yang dapat dengan mudah memahami ketika menerima suatu penjelasan, tetapi ada pula peserta didik yang sulit memahami yang dijelaskan. Jika peserta didik yang sulit memahami tersebut merasa cemas maka mereka tidak akan ragu untuk berusaha lebih keras untuk memahami. 
Desimal, 2 (1), 2019 - 51

Wantika, Sri Purwanti Nasution

Tetapi, kecemasan yang berlebihan juga berdampak buruk pada diri mereka karena dapat mengurangi efektivitas dari usaha yang mereka lakukan. Ketika kecemasan meningkat pada diri peserta didik, peserta didik akan berusaha lebih keras, tetapi pemahaman mereka justru semakin memburuk yang berakibat kecemasan mereka justru semakin meningkat. Terjadi terus-menerus hingga terbentuk "lingkaran setan". Hal tersebut dapat terjadi dalam jangka pendek dan juga jangka panjang. Pengalaman tersebut dalam pelajaran Matematika akan menjadi stimulus terhadap kecemasan. Oleh karena itulah peserta didik belajar secara parsial. Hal tersebut akan membentuk pengalaman interpersonal peserta didik.

Berdasarkan hasil penelitian terdahulu, telah dilakukan penelitian untuk menganalisis faktor-faktor kesulitan belajar peserta didik pada pembelajaran matematika (Huda \& Kencana, 2013; Novferma, 2016; Pawestri, Soeyono, \& Kurniawati, 2013; Sholihah \& Afriansyah, 2017; Tias \& Wutsqa, 2015; Untari, 2013; Widyasari, Meter, \& Negara, 2015; Yuwono, 2016), akutansi (Chesaria, Adi, \& Muchsini, 2015; Marsita, Priatmoko, \& Kusuma, 2010; Wulandari, Djaja, \& Suharso, 2014), fisika(Mahrus, 2013) dan kimia (Ristiyani \& Bahriah, 2016) serta kecemasan belajar matematika telah digunakan dalam beberapa penelitian terdahulu (Anita, 2014; Fariha, 2013; Handayani, 2016; Kurniawati \& Siswono, 2014; Marliani \& Hakim, 2015; Ningsih, 2016; Suci \& Purnomo, 2016; Syafri, 2017). Namun, belum terdapat penelitian sebelumnya yang menganalisis kesulitan belajar terhadap kecemasan peserta didik.

Seorang pendidik harus mampu dan memahami karakteristik peserta didik untuk mengatasi masalah belajar perlu mengadakan pendekatan pribadi di samping pendekatan instruksional dalam berbagai bentuk kemungkinan guru dapat lebih mengenal dan memahami peserta didik serta masalah belajarnya terutama pada tingkat kecemasan yang sangat mempengaruhi hasil belajar peserta didik pada pembelajaran Matematika khusunya. Berdasarkan latar belakang tersebut maka, penulis tertarik untuk meneliti permasalahan dengan judul "Analisis Kesulitan Belajar dalam Memahami Kecemasan Peserta Didik pada Pembelajaran Matematika di SMA Muhammadiyah 1 Kotaagung".

\section{METODE}

Berdasarkan masalah yang diteliti, maka penelitian ini dapat digolongkan kedalam penelitian kualitatif. Penelitian kualitatif adalah penelitian yang bermaksud untuk memahami fenomena tentang apa yang dialami oleh subjek penelitian, misalnya perilaku, persepsi, motivasi, tindakan, dan lainnya secara holistic, dan dengan cara deskripsi dalam bentuk kata-kata dan bahasa, pada suatu konteks khusus yang alamiah dan memanfaatkan berbagai metode alamiah (Moleong, 2001). Waktu pelaksanaan penelitian ini dilaksanakan pada bulan November 2016. Lokasi penelitian ini bertempat di SMA Muhammadiyah 1 Kotaagung yang beralamat di Jl. Samudera No.33 Kotaagung Kabupaten Tanggamus Provinsi Lampung.

Variabel independent (bebas) dan variabel dependent (terikat) pada penelitian ini antara lain: Kesulitan Belajar (X) sebagai variabel bebas, kecemasan peserta didik (Y1) dan Pembelajaran Matematika (Y2) sebagai variabel terikat. Subjek penelitian diartikan sebagai informan. Informan adalah orang dalam latar penelitian. Pemilihan subjek dalam penelitian ini adalah purposive sampling yaitu penentuan sampel dengan pertimbangan tertentu (Sugiyono, 2011). Sampling yang dimaksud pada penelitian kualitatif adalah untuk menyaring sebanyak 
Desimal, 2 (1), 2019 - 52

Wantika, Sri Purwanti Nasution

mungkin informasi dari berbagai macam sumber dan bangunannya (construction). Oleh sebab itu, penelitian kualitatif tidak ada sampel acak, tetapi sampel bertujuan (purposive sample)

Pengumpulan data yang digunakan penelitian ini menggunakan observasi, angket dan wawancara. Teknik pengumpulan data merupakan langkah yang paling strategis dalam penelitian, karena tujuan utama dari penelitian adalah mendapatkan data Populasi dalam penelitian ini adalah kelas X MIA 1 dan X IIS 2 yang berjumlah 74 peserta didik. Sementara itu sample yang digunakan yaitu kelas X IIS 2 berjumlah 37 peserta didik dan sisanya untuk uji coba instrumen. Uji coba instrumen menggunakan bantuan program Microsoft Excel 2010.

\section{HASIL DAN PEMBAHASAN}

Penelitian dilakukan di SMA Muhammadiyah 1 Kotaagung Kabupaten Tanggamus tahun pelajaran 2016/2017. Subjek dalam penelitian ini adalah peserta didik kelas $\mathrm{X}$ yang mengidentifikasi kesulitan belajar dalam masalah kecemasan pada pembelajaran Matematika. Penulis mengujikan di kelas $\mathrm{X}$ IIS 2 yang berjumlah 37 peserta didik sebagai sasaran penelitian atas anjuran guru Matematika yang telah memahami keadaan peserta didik setelah itu dipilih 1 dari masing-masing 3 kategori yaitu tingkat kecemasan tinggi, sedang dan rendah serta peneliti menguji secara mendalam ketiga subjek tersebut untuk dianalisis dengan memperhatikan kecenderungan responden menjawab pada soal deskripsi angket kecemasan kemudian dengan cara mewawancarai untuk mendapatkan informasi yang relevan.

Berdasarkan hasil angket kecemasan peserta didik pada pembelajaran Matematika tersebut, akan dianalisis penyebab peserta didik $\begin{array}{lrr}\text { mengalami } & \text { kecemasan } & \text { pada } \\ \text { pembelajaran } & \text { Matematika } & \text { sehingga }\end{array}$ menyebabkan peserta didik kesulitan belajar Matematika. Selanjutnya peserta didik yang telah dipilih dalam masingmasing 3 kategori yaitu tingkat kecemasan tinggi, sedang dan rendah akan diwawancarai mengenai alasan peserta didik mengalami kecemasan pada pembelajaran Matematika dengan memberikan wawancara dalam bentuk tanya jawab. Pemilihan waktu untuk wawancara dilakukan atas dasar kesepakatan antara penulis dengan peserta didik. Hal ini dimaksudkan agar tidak mengganggu kegiatan atau aktivitas belajar peserta didik disekolah.

Hasil observasi kesulitan belajar dalam masalah kecemasan pada pembelajaran Matematika di kelas X IIS 2 diperoleh data yang menunjukkan bahwa pembelajaran yang dilakukan oleh guru kurang bisa menumbuhkan semangat belajar peserta didik. Metode yang digunakan guru adalah metode ceramah yakni guru sebagai media penyampai informasi sedangkan peserta didik mempunyai peran sebagai pendengar.

Sifat pengajaran yang bersifat monoton dan kurang melibatkan partisifasi aktif dari peserta didik ini yang menyebabkan timbulnya rasa enggan mendengarkan penjelasan guru, malas berfikir, malas menyalin, penjelasan guru, sehingga materi pada pembelajaran dianggap sulitpun menjadi lebih mudah diabaikan. Kesiapan dan keaktifan peserta didik dalam pembelajaran juga dapat dikatakan masih rendah. Karena pada saat pengajaran dimulai masih terdapat peserta didik yang tidak membawa buku paket bahkan tidak membawa buku catatan Matematika. Sedangkan keaktifan peserta didik dalam pembelajaran tercermin pada saat kegiatan belajar, hanya sedikit peserta didik yang mengajukan pertanyaan kepada guru tentang materi yang disampaikan oleh guru. 
Desimal, 2 (1), 2019 - 53

Wantika, Sri Purwanti Nasution

Sebelum penelitian, penelitian melakukan kegiatan prapenelitian terlebih dahulu. Tindakan tersebut bertujuan untuk memperoleh informasi awal tentang aktivitas peserta didik selama proses pembelajaran yang biasa dilakukan oleh guru dan pengumpulan data yang digunakan untuk menganalisis kesulitan belajar dalam memahami kecemasan peserta didik pada pembelajaran Matematika. Penelitian ini dilakukan pada kelas X IIS 2 di SMA Muhammadiyah 1 Kotaagung Kabupaten Tanggamus untuk mengetahui bagaimanakah Kesulitan Belajar Dalam Memahami Kecemasan Peserta Didik Pada Pembelajaran Matematika serta mengetahui faktor-faktor yang mempengaruhinya.

\section{Validitas Instrument Deskripsi Uji Angket}

Subjek dalam penelitian ini adalah ini adalah peserta didik kelas X sebanyak 2 kelas, 1 kelas untuk uji coba dan 1 kelas untuk kelas yang diteliti. Kelas yang menjadi uji coba yaitu kelas X MIA 1 dengan jumlah 37 peserta didik dan kelas yang fokus penelitian yaitu kelas X IIS 2 dengan jumlah 37 peserta didik. Penelitian ini dilaksanakan pada bulan Oktober-November 2016 semester ganjil tahun ajaran 2016/2017 yang mangacu pada kalender akademi sekolah untuk mata pelajaran Matematika. Penulis mengambil subjek dalam penelitian ini adalah purposive sampling yaitu penentuan sampel dengan pertimbangan tertentu. Sampling yang dimaksud pada penelitian kualitatif adalah untuk menyaring sebanyak mungkin informasi dari berbagai macam sumber dan bangunannya (construction). Oleh sebab itu, penelitian kualitatif tidak ada sampel acak, tetapi sampel bertujuan (purposive sample). "sampel bertujuan ditandai dengan sampel yang tidak dapat ditentukan atau ditarik lebih dahulu dan jumlah sampel ditentukan oleh pertimbangan-pertimbangan, informasiinformasi yang diperlukan". Subjek penelitian dalam penelitian ini adalah peserta didik kelas $\mathrm{X}$ IIS 2 SMA Muhammadiyah 1 Kotaagung Kabupaten Tanggamus. Dimana peserta didik kelas X IIS 2 tersebut berjumlah 37 peserta didik, peneliti mengamati peserta didik yang berjumlah 37 tersebut dengan terjun langsung ke lapangan.

Sebelum melakukan wawancara penelitian ini menggunakan angket untuk mengetahui masalah kesulitan belajar dalam memahami kecemasan peserta didik pada pembelajaran Matematika. Angket yang digunakan terlebih dahulu di validasi kepada yang ahli dalam bidangnya kemudian diujicobakan dikelas berbeda untuk mencari valid atau tidaknya angket yang akan diterapkan pada penelitian tersebut. Ketika sudah valid maka angket diterapkan pada kelas yang akan diteliti untuk melihat apakah memang benar kecemasan adalah faktor dari kesulitan belajar tersebut. Setelah angket selesai maka peserta didik yang menjadi focus peneliti akan diambil sampel 3 kategori yaitu kecemasan tinggi, kecemasan sedang dan kecemasan rendah kemudian dilakukan wawancaralebih lanjut agar data yang akan dicari semakin valid.

Perhitungan uji reliabilitas dengan menggunakan rumus Alpha, dengan kesimpulan yaitu instrumen dikatakan reliabel jika reliabilitasnya lebih besar dari atau sama dengan 0,70 ( $\mathrm{r}_{\text {hitung }} \geq$ 0,70). Berdasarkan hasil perhitungan yang telah dilakukan, menunjukkan bahwa indeks reliabilitas angket disposisi matematis adalah 0,92. Sehingga angket tersebut dinyatakan reliabel dan memenuhi kriteria layak digunakan sebagai instrumen penelitian.

Angket kecemasan diberikan kepada peserta didik yang dilaksanakan pada hari Senin tanggal 07 November 2016 pukul 07.40 sampai dengan 09.00 
Desimal, 2 (1), 2019 - 54

Wantika, Sri Purwanti Nasution

WIB. Hasil angket kecemasan peserta didik dapat dilihat pada Tabel 1.

\begin{tabular}{ccc}
\multicolumn{3}{c}{ Tabel 1. Hasil Angket Kecemasan } \\
\hline No & $\begin{array}{c}\text { Kategori Tingkat } \\
\text { Kecemasan }\end{array}$ & $\begin{array}{c}\text { Banyaknya } \\
\text { Peserta Didik }\end{array}$ \\
1 & $\begin{array}{l}\text { Tingkat Kecemasan } \\
\text { Tinggi }\end{array}$ & 8 \\
2 & $\begin{array}{l}\text { Tingkat } \quad \text { Kecemasan } \\
\text { Sedang } \\
3\end{array}$ & $\begin{array}{l}\text { Tingkat Kecemasan } \\
\text { Rendah }\end{array}$ \\
\hline
\end{tabular}

Berikut uraian dari hasil skor ratarata gabungan dari kriteria positif dan negatif tiap kondisi, dan skor data angket tingkat kecemasan peserta didik dalam pembelajaran Matematika yang peneliti sajikan dalam tiap indikator berdasarkan persentase skor angket dapat dilihat pada Tabel 2.

Tabel 2. Interval Skor Tingkat Kecemasan

\begin{tabular}{|c|c|}
\hline $\begin{array}{l}\text { Kategori Tingkat } \\
\text { Kecemasan }\end{array}$ & Skor \\
\hline $\begin{array}{l}\text { Tingkat Kecemasan } \\
\text { Sangat Tinggi }\end{array}$ & $4,50 \leq X \leq 5,00$ \\
\hline $\begin{array}{l}\text { Tingkat Kecemasan } \\
\text { Tinggi }\end{array}$ & $3,50 \leq X \leq 4,49$ \\
\hline $\begin{array}{l}\text { Tingkat } \\
\text { Sedang }\end{array}$ & $2,50 \leq X \leq 3,49$ \\
\hline
\end{tabular}

Pengambilan subjek secara purposive terpilih 3 orang peserta didik yang selanjutnya dilakukan wawancara pertama dan kedua. Wawancara tersebut dilakukan dengan hari yang berbeda antara peserta didik yang satu dengan yang lainnya. Ketiga orang peserta didik tersebut adalah peserta didik KT sebagai subjek penelitian untuk kategori kecemasan tinggi, peserta didik KS sebagai subjek penelitian untuk kategori kecemasan sedang, dan peserta didik KR sebagai subjek penelitian untuk kategori kecemasan rendah.

Teknik pengambilan data pada penelitian tugas berbasis wawancara ini menggunakan teknik tringulasi waktu, sehingga peneliti perlu menggunakan hari yang berbeda untuk setiap wawancara pada 3 subjek penelitian. Untuk pemilihan waktu, peneliti menyesuaikan dengan keadaan dan waktu sekolah serta dengan menyesuaikan waktu dengan peserta didik. Wawancara dilaksanakan pada hari yang sama setelah peserta didik selesai mengerjakan soal pemecahan masalah Matematika. Peneliti menggunakan batuan media berupa handpone untuk merekam hasil wawancara.

\section{Analisis Instrumen}

Uji instrumen tes uraian dilakukan pada kelas uji coba yaitu kelas X MIA 1 dengan jumlah 37 peserta didik. Soal uji coba yang digunakan dalam penelitian berupa soal angket sebanyak 35 item selanjutnya adalah menganalisis hasil uji coba soal yang meliputi: validitas dan realibilitas. Berdasarkan angket yang telah diujikan bahwa dari 35 butir soal angket yang di uji cobakan sebanyak 34 butir soal dikatakan valid dan 1 butir soal dinyatakan tidak valid. Suatu butir soal dikatakan valid jika $r_{\text {hitung }} \geq r_{\text {kritis }}(0,30)$, artinya butir soal tersebut tepat dan layak digunakan untuk pengukuran dalam rangka pengumpulan data dan dikatakan tidak valid jika $r_{\text {hitung }}<r_{\text {kritis }}(0,30)$, artinya butir soal tersebut tidak layak digunakan untuk pengukuran dalam rangka pengumpulan data.

Peneliti melakukan pembahasan hasil dari penelitian yang dilakukan untuk mengetahui tingkat kecemasan peserta didik dalam pembelajaran Matematika. Hasil tersebut dapat diketahui melalui angket. Berdasarkan identifikasi masalah bahwa kurangnya dorongan yang mendasar dan alasan peserta didik mengalami kecemasan.

Berbagai penelitian menganalisis tentang kesulitan belajar matematika. Ayu Aji Wedaring Tias menganalisis kesulitan belajar siswa dalam pemecahan masalah matematika. Dari hasil penelitiannya dapat disimpulkan bahwa 
Desimal, 2 (1), 2019 - 55

Wantika, Sri Purwanti Nasution

faktor-faktor kesulitan yang dialami siswa dalam memecahkan masalah matematika yakni: siswa kurang teliti, tergesa-gesa dalam mengerjakan soal, lupa, kurang waktu untuk mengerjakan soal, cepat menyerah, terkecoh, dan cemas (Tias \& Wutsqa, 2015). Selain itu faktor-faktor kesulitan belajar matematika dalam implementasi kurikulum 2013 meliputi faktor internal dan eksternal. Faktor internal meliputi minat, motivasi, intelegensi dan faktor eksternal meliputi faktor guru serta buku siswa (Widyasari et al., 2015).

Berdasarkan penelitian terdahulu, keterbaruan dalam penelitian ini yaitu menganalisis kesulitan belajar dalam memahami kecemasan peserta didik pada pembelajaran matematika di SMA Muhammadiyah 1 Kota Agung. Dalam hal ini dapat disimpulkan bahwa faktor yang mempengaruhi kesulitan belajar yaitu faktor internal fisik dan fisikis serta faktor eksternal yaitu faktor keluarga dan lingkungan. Kecemasan peserta didik dengan kategori kecemasan rendah lebih terlihat tanggap dan sangat bersemangat dalam pembelajaran Matematika dibandingkan dengan dua kategori lainnya yaitu kategori kecemasan sedang dan kecemasan tinggi.

\section{SIMPULAN DAN SARAN}

Berdasarkan hasil analisis data dan pembahasan, maka diperoleh kesimpulan faktor-faktor yang menyebabkan peserta didik mengalami kesulitan belajar dalam masalah kecemasan pada pembelajaran Matematika adalah (a). Peserta didik kurang menguasai konsep-konsep sebelumnya yang digunakan dalam materi yang dipelajari (b). Cara pembelajaran yang monoton sehingga peserta didik malas, bosan, yang menjadikan minat peserta didik rendah dalam belajar Matematika. (c). kurangnya perhatian guru kepada peserta didik yang tingkah kemampuan pemahamannya rendah. (d). Kurangnya perhatian orang tua dalam perkembangan belajar peserta didik.

\section{DAFTAR PUSTAKA}

Aminullah, M. A. (2013). Kecemasan antara Siswa SMP dan Santri Pondok Pesantren. Jurnal Ilmiah Psikologi Terapan, 1(2), 205-215.

Anita, I. W. (2014). Pengaruh Kecemasan Matematika (Mathematics Anxiety) Terhadap Kemampuan Koneksi Matematis Sisiwa SMP. Infinity: Jurnal Ilmiah Program Studi Matematika STKIP Siliwangi Bandung, 3(1), 125-132.

Chesaria, R. D., Adi, W., \& Muchsini, B. (2015). Analisis Faktor-Faktor Penyebab Kesulitan Belajar Akuntansi Perusahaan Jasa Siswa Kelas X Akuntansi SMK Negeri 1 Surakarta Tahun Ajaran 2014/2015. Jurnal "Tata Arta" UNS, 1(1), 94-103.

Fariha, M. (2013). Kemampuan Berpikir Kritis Matematis dan Kecemasan Matematika dalam Pembelajaran dengan Pendekatan Problem Solving (Studi Eksperimen pada Kelas X MAN Rukoh Kota Banda Aceh). Jurnal Peluang, 1(1), 43-50.

Handayani, S. D. (2016). Pengaruh Konsep Diri dan Kecemasan Siswa Terhadap Pemahaman Konsep Matematika. Jurnal Formatif, 6(1), 23-34.

Huda, N., \& Kencana, A. G. (2013). Analisis Kesulitan Siswa Berdasarkan Kemampuan Pemahaman dalam Menyelesaikan Soal Cerita pada Materi Kubus dan Balok Di Kelas VIII SMP Negeri 30 Muaro Jambi. In Semirata 2013 FMIPA Unila (pp. 595606).

Janurti, N. K., Dibia, I. K., \& Widiana, I. W. (2016). Analisis Kesulitan Belajar dalam Pembelajaran Membaca Cepat Siswa Kelas V SD Gugus VI Kecamatan Abang. E-Journal PGSD 
Desimal, 2 (1), 2019 - 56

Wantika, Sri Purwanti Nasution

Universitas Pendidikan Ganesha, 4(2), 1-10.

Kumalasari, A., \& Sugiman. (2015). Analisis Kesulitan Belajar Mahasiswa pada Mata Kuliah Kapita Selekta Matematika Sekolah Menengah. JURNAL RISET PENDIDIKAN MATEMATIKA, 2(1), 16-27.

Kurniawati, A. D., \& Siswono, T. Y. E. (2014). Pengaruh Kecemasan dan Self Efficacy Siswa Terhadap Kemampuan Pemecahan Masalah Materi Segiempat Siswa Kelas VII MTs Negeri Ponorogo. MATHEdunesa Jurnal Ilmiah Pendidikan Matematika, 3(2), 36-41.

Lestari, A. S. B. (2015). Analisis Kesulitan Mahasiswa Program Studi Pendidikan Matematika STKIP PGRI Pasuruan pada Pokok Bahasan Teknik Pengintegralan. Jurnal Psikologi, III(1), 20-27.

Mahrus, A. (2013). Mengatasi Kesulitan Belajar melalui Klinik Pembelajaran (Studi Analisis pada Mata Pelajaran Fisika). KONSELING RELIGI: Jurnal Bimbingan Konseling Islam, 4(2), 263-294.

Marliani, N., \& Hakim, A. R. (2015). Pengaruh Metode Belajar dan Kecemasan Diri Terhadap Hasil Belajar Matematika Peserta Didik. JKPM, 1(1), 136-150.

Marsita, R. A., Priatmoko, S., \& Kusuma, E. (2010). Analisis Kesulitan Belajar Kimia Siswa SMA dalam Memahami Materi Larutan Penyangga dengan Menggunakan Two-Tier Multiple Choice Diagnostic Instrument. Jurnal Inovasi Pendidikan Kimia, 4(1), 512520.

Moleong, L. (2001). Metodologi Penelitian Kualitatif. Bandung: Remaja Rosda Karya.

Ningsih, E. F. (2016). Proses Berpikir Mahasiswa dalam Pemecahan Masalah Aplikasi Integral Ditinjau dari Kecemasan Belajar Matematika(Math Anxiety). Iqra',
1(2), 191-216.

Novferma, N. (2016). Analisis Kesulitan dan Self-Efficacy Siswa SMP dalam Pemecahan Masalah Matematika Berbentuk Soal Cerita. JURNAL RISET PENDIDIKAN MATEMATIKA, 3(1), 76-87.

Pawestri, U., Soeyono, \& Kurniawati, I. (2013). Analisis Kesulitan Pembelajaran Matematika dengan Pengantar Bahasa Inggris pada Materi Pokok Bentuk Logaritma Kelas X Imersi SMA Negeri Karangpandan Karanganyar 2012/2013. Jurnal Pendidikan Matematika Solusi, 1(1), 1-7.

Ristiyani, E., \& Bahriah, E. S. (2016). Analisis Kesulitan Belajar Kimia Siswa di SMAN X Kota Tangerang Selatan. Jurnal Penelitian Dan Pembelajaran IPA, 2(1), 18-29.

Sholihah, S. Z., \& Afriansyah, E. A. (2017). Analisis Kesulitan Siswa dalam Proses Pemecahan Masalah Geometri Berdasarkan Tahapan Berpikir Van Hiele [Penelitian Studi Kasus di Kelas VII SMP Negeri 6 Garut]. Jurnal "Mosharafa," 6(2), 287-298.

Solihah, F. I., \& Liana, C. (2017). Pengaruh Tingkat Kecemasan Siswa Terhadap Prestasi Belajar Sejarah Siswa Kelas $\mathrm{X}$ IPS 2 SMAN 12 Surabaya. AVATARA: E-Journal Pendidikan Sejarah, 5(3), 1138-1150.

Suci, V. W., \& Purnomo, Y. W. (2016). Hubungan antara konsepsi penilaian dan kecemasan siswa sekolah dasar di kelas matematika. Beta Uurnal Tadris Matematika), 9(1), 48-60.

Sugiyono. (2011). Metode Penelitian Kuantitatif Kualitatif dan R\&D. Bandung: Alfabeta.

Syafri, F. S. (2017). Ada Apa dengan Kecemasan Matematika? Journal of Mathematics Education IKIP Veteran Semarang, 1(1), 59-65.

Tias, A. A. W., \& Wutsqa, D. U. (2015). Analisis Kesulitan Siswa SMA dalam Pemecahan Masalah Matematika 
Desimal, 2 (1), 2019 - 57

Wantika, Sri Purwanti Nasution

Kelas XII IPA di Kota Yogyakarta. JURNAL RISET PENDIDIKAN MATEMATIKA, 2(1), 28-39.

Untari, E. (2013). Diagnosis Kesulitan Belajar Pokok Bahasan Pecahan pada Siswa Kelas V Sekolah Dasar. Jurnal Ilmiah STKIP PGRI Ngawi, 13(1), 1-8.

Widyasari, N. M. D., Meter, I. G., \& Negara, I. G. A. O. (2015). Analisis KesulitanKesulitan Belajar Matematika Siswa Kelas IV dalam Implementasi Kurikulum 2013 di SDpiloting SeKabupaten Gianyar. E-Journal PGSD
Universitas Pendidikan Ganesha, 3(1). Wulandari, M., Djaja, S., \& Suharso, P. (2014). Analisis Kesulitan Belajar Akuntansi Pada Materi Jurnal Penyesuaian (Studi Kasus Pada Siswa Kelas XI IPS di SMA Negeri 1 Pakusari Tahun Ajaran 2013-2014). JURNAL EDUKASI UNEJ, 1(2), 23-27.

Yuwono, M. R. (2016). Analisis Kesulitan Belajar Siswa Kelas VII SMP dalam Menyelesaikan Soal Materi Segitiga dan Alternatif Pemecahannya. Magistra, XXVIII(95), 14-25. 